\title{
Polish Research on the History of Byelorussia in the Feudal Epoch
}

\author{
BY \\ J. OCHMAŃSKI \\ (translated by J. Dingley)*
}

A particularly significant contribution to research on the history of Byelorussia in the feudal epoch has been made by the Poznan school, led and inspired by prof. dr H. Lowmianski, in the work of S. Kasperczak, S. Alexandrowicz, J. Morzy and J. Ochmański. The following themes have been predominant in this research: 1) studies on the internal history of Byelorussia, and 2) the historical cartography of Byelorussia.

A characteristic feature of the economic development of central and eastern Europe in the 15th-18th centuries was the development of manorial estates producing a surplus for sale. Thanks to the studies of Polish historians, in particular W. Rusiński, J. Topolski and A. Wyczański, we know a great deal about the manorial serf economy of Poland during that period. An important contribution to our understanding of the problem was made by $\mathrm{S}$. Kasperczak in his monograph Rozwój gospodarki folwarcznej na Litwie i Białorusi do połowy XI wieku. ${ }^{1}$ In this work, which draws chiefly on Byelorussian material, the author deals 'with the early stages of the development of the manorial estate. He shows that the personal land holdings of the feudal lord date back to the tribal era. At that time, however, they were not large, being limited to the average boyar estate with a small area of arable land, for hay and other crops. Such holdings were, however, a common feature and they developed where feudal ownership of land existed, as well as in the prince's possessions.

In the 15th century, in connection with the rapid growth of large landholdings, ${ }^{2}$ the author notes the continued development of rural estates, which increase in both number and size. He links this phenomenon with the development of commodity and money relations in the country, and also with the increased opportunities for exporting agricultural produce in the second half of the 15th century. Crop production and animal breeding predominated in these estates.

The main labour force on the feudal lord's private estate in the earliest period was made up of bonded retainers. Later, at the end of

\footnotetext{
* Translator's note

Owing to the delays experienced in communication with Poland, the translation was checked only once by the author. Although points raised by him were incorporated into the final version printed here, some difficulties remain which had not been fully settled. It was nevertheless decided that publication of this important survey should not be delayed further. Any mistakes or discrepancies should be regarded as translator's errors.
} 
the 15 th and the beginning of the 16 th centuries, a start was made on drawing dependent serfs into the labour force by means of corvée. The manor organized a whole range of specialized services, i.e. grooms, keepers of wild forest bees, beaver catchers, dog handlers, hunters, beaters (forest guards). In addition the manor gave employment to various types of craftsmen, and from time to time used hired labour.

In his pioneering studies $\mathrm{S}$. Alexandrowicz has raised an issue never touched upon before in historical writing: the development of the economic role of townships (miasteczko) in Byelorussia. ${ }^{3} \mathrm{He}$ is prinarily concerned with the origin and growth of townships in Lithuania and Byelorussia up to the middle of the 17th century. He has compiled chronological information on the origins of townships in Byelorussia. He has ascertained that such townships are first mentioned in the 15th century, but that much more information has been preserved relating to the 16 th and first half of the 17 th centuries.

On the basis of the material studied Alexandrowicz observes that the oldest of the townships are those settlements which developed alongside royal castles or the castles of great feudal lords. However, by far the greatest number of such townships grew out of markets and centres where craftsmen lived next to manorial estates. Many townships grew up in the middle of the 16th century and later during Queen Bona's land survey (pomiara włóczna), often in harsh conditions or even in the forests. Alexandrowicz asserts that the decisive factor leading to the rise of townships was the need to service routes of communication. On the basis of abundant source material he concludes that the period of development of townships in Byelorussia and Lithuania extended from the beginning of the 15th to the middle of the 17th century, with a large number of them already established by the end of the 15 th century.

By compiling numerical data Alexandrowicz has established that by the middle of the 17th century there were altogether 803 townships on the territory of the Grand Duchy of Lithuania. One township served an average area of 370 sq.km. The greatest density of townships was found in the province (województwo) of Navahrudak and in western Byelorussia; there were fewer in the east of the country. By taking into consideration the information contained in Tomasz Makowski's map of the Grand Duchy of Lithuania, ${ }^{4}$ which is an essential addition to the direct source references, Alexandrowicz concludes that by the middle of the 17 th century there were more than 900 towns and townships in the Grand Duchy.

In a separate essay Alexandrowicz has made a study of the population of towns and townships in Lithuania and Byelorussia in the same period. ${ }^{5}$ Here he attempts to define the term miasteczko (township). In his opinion the economic functon of the township made it a link between village and large town; it was moreover a centre of trade, it contained a significant number of inns and more craftsmen than the village. The township nevertheless resembled the village in that the primary occupation of the population was agriculture. Alexandrowicz also employs numerical criteria. In his view the township was a settlement of up to 300 homesteads $(d y m)$, with on average eight persons 
to one homestead. From these figures one may conclude that a township was inhabited by at most 2,000 persons.

Alexandrowicz has also made a study of the nature of employment and production in the townships of Byelorussia and Lithuania in the period 16 th to mid-17th centuries. ${ }^{*}$ He links the earliest stages of development of trades within the townships with their role as the economic centre of the manorial estate, i.e. as administrative centres. An examination of the specializations to be found in township trades and crafts has led Alexandrowicz to the conclusion that the most important were those primarily concerned with metalworking and food production. Nevertheless there were in the townships other craftsmen: tanners, tailors, builders, and at times even some who provided cultural services such as school-teachers and clowns.

In summing up his conclusions Alexandrowicz has become convinced that craft specialization in the townships was not great. He has at the same time ascertained that there were no guilds there either. Of equal importance is his view that thcre are no signs pointing to an economic decline before the middle of the 17 th century. In his review article 'Miasta Białorusi $w$ XVI i pierwszej połowie XVII wieku' Alexandrowicz critically examines Z. J. Kopysskij's monograph Ekonomičeskoje razvitije gorodov Belorusii $v$ XVI - pervoj polovine XVII $v$. (Minsk, 1966). He agrees with Kopysskij that the view advanced by old historians on the agricultural nature of Byelorussian towns is without foundation, and that the decisive factors for the origin and growth of towns were crafts and trade. At the same time Alexandrowicz takes issue with Kopysskij on the question of the adverse effect of the Union of Lublin on the development of Byelorussian towns. In Alexandrowicz's view there can be no question of fiscal pressure being exerted on Byelorussian towns by Polish feudal lords.

An important contribution to the study of the history of Byelorussian towns is Alexandrowicz's study of the drawing of $\mathbf{S}$. $\mathrm{Pa}-$ chołowiecki 'Nowe źródła ikonograficzne do oblężenia Połocka w 1579 roku'. ${ }^{8}$ Basing his findings on this drawing, he provides new information on the architecture of the cathedral of St Sophia in Polack. He established that it was similar to the cathedral of St Sophia in Novgorod the Great, in that it had seven cupolas.

Alexandrowicz has also published an article entitled 'Ordynacja miasta Lubcza nad Niemnem w 1657 roku'.

Of fundamental importance for an understanding of the historical depiction of the ancient lands of Byelorussia is Alexandrowicz's study 'Rozwój kartografii Wielkiego Księstwa Litewskiego od XV do połowy XVIII wieku'.10 $\mathrm{He}$ combines historical and cartographical studies which considerably enrich the content of his work and enable him to take a broad view of the problem. The author makes a unique and highly original contribution to the study of the Radziwiłł map of the Grand Duchy of Lithuania, which he had already examined in a separate publication. He deserves credit for his discovery that the edition of 1613 was not the first. He convincingly adduces data to show that a similar map had been published in 1603. In his opinion the 
Radziwiłł map is the supreme achievement of the cartography of the Grand Duchy of Lithuania in that period; the maps dating between 1650 and 1763 that he deals with next do not display any marked progress in the way in which European cartographers depict the territory of Byelorussia and Lithuania.

A fundamental topic of discussion in specialist literature has been broached by J. Ochmański. He has made a study of the employment of townspeople in the Grand Duchy of Lithuania in the 16th century. ${ }^{11}$ Drawing on the registers of the 'land reform' he has established the types of employment prevalent in Brest. Pinsk. Hrodna and other western Byelorussian towns. He has ascertained that $6-10 \%$ of the inhabitants of these three large towns owned farms. Farmers comprised a much larger percentage $(20-88 \%)$ of the population in large town-type settlements. Ochmański has also attempted to calculate the size of urban agricultural production and the extent to which it covered consumption. His calculations show that Byelorussian towns in the 16 th century were forced to rely heavily on village produce, especially cereals, since their own production met no more than $10-60 \%$ of the amount needed. In his conclusion Ochmański asserts that all large towns of Byelorussia were non-agricultural in character.

Ochmański has also made a study of the ethnic structure of the Byelorussian village before the mid-16th century. In his opinion islands of homogeneous Lithuanian settlement in Byelorussia still existed in the middle ages; he takes as an example the estate of Obolce in eastern Byelorussia. ${ }^{12}$ An interest in the ethnic composition of the Byelorussian lands leads Ochmański to attempt to explain the building in Obolce of a Catholic church endowed by Władysław Jagiełło in 1387. In Ochmański's opinion it was not built there by chance. He puts forward evidence to show that Obolce was inhabited by Lithuanians in the 15th and 16th centuries; he considers that this was not the result of colonization but an island of old Baltic settlement.

Ochmański's work has also been concerned with socio-economic relations in the Byelorussian village in the second half of the 16th and the first half of the 17 th centuries. He has made a study of the socio-economic position and class struggle of peasants in Kobryn district (powiat) in that period. ${ }^{13} \mathrm{He}$ has established the extent, population and social composition of Kobryn district in the 16 th century.

With a surface area of 3,430 sq. $\mathrm{km}$. the county had at that time at least 32,000 inhabitants. The article also contains data on agricultural methods. The main emphasis was placed on taxing the peasant. An increase was noted in the taxes imposed on the Kobryn peasants, in cash and kind. An interesting attempt was made to assess both the income from a peasant farm of one włóka (16.8 ha $=42$ acres) and the ground-rent exacted from such a farm. Ochmański concludes that at the end of the 16 th century in Kobryn county the peasant provided $22-30 \%$ pure income for the landlord.

Ochmański continued this study with an article devoted to the development of large manorial estates from the end of the 16th and beginning of the 17 th centuries in the same area. He draws attention 
to the fact that the starting point for the development of the manorial estate in Kobryn county was the 'land survey', as a result of which there was a huge increase in the so-called 'manorial ploughlands'; indeed, in Kobryń county they expanded to 30 włóki, i.e. they exceded 600 ha. ${ }^{14} \mathrm{He}$ also notes the significant development of the large manorial estate based on villein labour in the county and the part it played in exporting grain along the Bug and Vistula to Gdansk. ${ }^{15}$ The same author has collected the views expressed in the specialist literature on the land reform; on the one hand the reform was regarded as progressive, on the other as reactionary. The progressive side of the reform is seen in the introduction of new farming methods (the three-field system), whereas it was reactionary in considerably increasing the obligations of the serfs.

M. Kosman has made a study of the land survey question in the Pinsk area of Paleśsie. ${ }^{16}$ Here the reform was carried out twice: in 1522-3 and 1561-6. The first was made on the orders of Queen Bona, the second on those of Sigismund II Augustus. The author has calculated that 997.38 włóki were surveyed in Pinsk county, and only 549.68 in Kłeck county. The survey of 1561-6 shows that a much greater number of wlóki in Pinsk county were included. The author does not establish the causes of such a significant difference. Kosman's observation that the land survey did not lead to the development of large estates in Pinsk county and that money rent still predominated, is extremely important but not unexpected.

The class struggle on the Byelorussian-Lithuanian border in the middle of the 16th century forms the basis of J. Kazimierski's publication 'Opisanie krzywd wyrządzonych poddanym w dobrach Holszany i Pasikiszki na Białorusi w 1554 roku' ${ }^{17}$

One of the important achievements of Polish historiography is that historians have focussed attention on hitherto little-known aspects of the history of eastern Byelorussia. M. B. Topolska has achieved special distinction in this area for her study of the history of the Skłoŭ estates in eastern Byelorussia in the 17 th and 18 th centuries, ${ }^{18}$ and of the development of the town of Skłou. ${ }^{19}$ Her researches have shown that Skłoŭ was the centre of a large estate complex, belonging in the first half of the 16th century to the Gasztold family, then to the Chodkiewicz family, after them to the Sieniawskis, finally to the Czartoryski family.

Topolska's work on Škłoŭ throws indirect light on the other urban centres of eastern Byelorussia (apart from Mahiloŭ) so far unresearched. She has also made a study of the trade connections of eastern Byelorussia with Riga at the end of the 17 th and the beginning of the 18th centuries. ${ }^{20}$ On the basis of new source material she has shown that the lords of Skłoŭ derived huge profits from the Riga trade. They bought, or received as rent, hemp from the peasants and sent it downriver to Riga. The author also deals with the organization of trade with Riga. On the return journey the lords of Skłoŭ brought salt, which they sold on the spot at a correspondingly high profit.

In her study of the Skłoŭ estates Topolska has established that at the end of the 16th and beginning of the 17 th centuries they included 
160 villages, 2 townships and one town, covering an area of some $1,000 \mathrm{sq} . \mathrm{km}$. on both sides of the Dnieper between Orša and Mahiloŭ. She has also shown that these estates differed in a number of significant ways from those of western Byelorussia in that we do not find there the growth of large estates worked by serf labour. She shows that the Skłoŭ village was to a considerable extent drawn into the sphere of monetary and commodity relations. Skłoŭ peasants brought to market grain, hops, hemp and livestock, and acquired salt, beer, vodka and agricultural implements.

Following J. Morzy, Topolska emphasizes that Orša district, in which Skłoŭ was situated, had a higher population density and a greater number of towns than the other powiaty of the Grand Duchy of Lithuania. On the basis of a series of 32 inventories dating from 1643-1717 the author has calculated the population of the town and estates of Skłoŭ.

In the first half of the 17 th century Skłoŭ was a large town with about 1,100-1,200 homesteads. In this respect it was the sixth largest town of the Grand Duchy, after Vilna, Mahiloŭ, Słuck, Minsk and Połack. In 1650 there were 5,390 homesteads on the Skłoŭ estates. Wars in the period between 1650 and 1750 caused a huge, more than five-fold population decrease. There was in the second half of the 18th century a significant growth in population, which in 1669 had amounted to 2,595 homesteads. Including the town of Skłoŭ, these estates numbered 6,610 homesteads in the middle of the 17 th century. In 1662 , in the period of the greatest decline in farming, there were 1,555 homesteads on the Skłoŭ estates, but by 1669 this figure had increased to 3,620 .

The author has also investigated the social structure of the Skłoŭ estates between the mid-17th and mid-18th centuries. According to her figures peasants comprised $70-79 \%$, townspeople $20-28 \%$, clergy $0.5-1 \%$, nobility $0.5-5 \%$ of the population.

She gives extensive data on the nature and size of animal and crop production on the Skłou estates. They include crop yield in the case of the main crop, winter rye, which amounted to an average of scarcely 2.5 grains to every grain sown. In the section on the economic and social position of the rural population Topolska, following Lowmianski and Ochmański, attempts to calculate the income of a peasant farm per włóka at the end of the 17th century. Crop production yielded $60 \%$, animal production and other activities gave $40 \%$ of income. In round figures according to her estimate the income amounted to 400 tynfy. Taxation of the peasant per wlóka together with corvée amounted to $40 \%$ of income.

The author has also shown the important trading role played by Skłoŭ as a centre of local, regional and foreign markets. Towns that were growing in economic importance and population, and in which only $10 \%$ of the population were engaged in agriculture, were destroyed in the wars which began in the second half of the 17 th century.

In a succinct article summarizing the results of extensive research, prof. dr H. Lowmiański discusses the data contained in the military reviews of 1528 and 1567 and relates them to the historical demo- 
graphy of the Grand Duchy of Lithuania in the 16th century. According to his calculations Lithuania and Byelorussia together with Podlasie contained more than 2 million inhabitants in 1528, whereas at the time of the negotiations on union with Poland in 1567 this figure excceded $2^{1 / 2}$ million. ${ }^{21}$

The latest contribution to the historical demography of Byelorussia is J. Morzy's monograph on the population crisis in Lithuania and Byelorussia in the second half of the 17 th century.22 Moreover Morzy has broached a hitherto unresearched problem and uses rich, chiefly archival source material. The work covers the years 1648-67, i.e. the period immediately before and during the Swedish and Muscovite wars. It is introduced by an extensive section on the course of military activities in the Grand Duchy in the period under discussion.

Using the figures of the hearth-tax register of 1649-50 Morzy has concluded that before the wars the Grand Duchy of Lithuania had $4,546,000$ inhabitants. This figure fell after the wars to $2,348,000$.

How did he arrive at these figures?

In calculating the population in the mid-17th century he first took the figure of 483,052 homesteads, to which he added $15 \%$ for people not included in the hearth-tax registers. He then multiplied the resulting figure of 528,296 by 8 , the accepted number of people per homestead. The resulting figure is $4,546,368$ (p. 136). In the hearth-tax registers after the wars Morzy found a total of 267,794 homesteads, which, with 7.5 persons per homestead, gives a population of $2,348,000$ (p. 147; in table 54 the author gives a figure of 2,346,000). According to his calculations the population density in Lithuania and Byelorussia was 15.3 persons per sq.km., which sank after the wars to 8 per sq.km. He draws attention in table 17 to the fact that the average population density in Byelorussia was lower than in Lithuania.

In his comprehensive monograph Szkice o manufakturach $w$ Polsce $X V I I I$ wiek $u^{2: 1} \mathrm{~W}$. Kula also includes information relating to factories on the Byelorussian territories. He discusses the activities of the Radziwiłł cloth-making factory in Niaśviž, which operated in 1752-64. The factory was set up by local people with local resources, and comprised a granary, dye-works, shearing shop and three weaving-mills. Kula has demonstrated the existence of cottage industry; he also discusses labour organization in the factory and shows that production was intended chiefly for the domestic market and scarcely covered costs. He also deals with the wages of the factory workers, noting a wide variation in them. It is clear from his work that the factory relied partly on serf labour.

Kula also writes about the large smelting works in Ruda near Brest, which was active between 1768 and 1789 and used local iron ore. Apart from the furnace itself the ironworks also included a watermill, a tannery, saw-mills and fineries. In all, the works employed 44 persons. Even so it relied to a large extent on corvée.

Both the cloth factory in Niaśviž and the ironworks in Ruda, apart from their use of forced labour, provide evidence of technical progress and of the development of productive forces in Byelorussia in the second half of the 18th century. 
The problem of the growth and organization of factories in Byelorussia has received detailed attention in $\mathrm{S}$. Kościalkowski's posthumously published monograph Antoni Tyzenhauz, podskarbi nadworny litewski. ${ }^{2+}$ The cautious, expert critic L. Żytkowicz has the following to say: 'This work is perhaps the most comprehensive study of the internal history of Byelorussia and Lithuania between the years $1765-1780^{\prime}{ }^{25}$

The third chapter of the first volume is especially worthy of attention. It is entitled 'Przemyśl, manufaktury, rzemiosła' (pp. 225-314). The author has established that Tyzenhauz founded about 50 factories on royal estates, chiefly in Byelorussia, of which more than 20 were in Hrodna. In his view the factories came into existence and then maintained themselves largely at the expense of the royal estates, using the free corvée of the local serfs. 1328 people were regularly employed in the Hrodna factories, not counting serf labourers.

Kula has also made a study of the Hrodna factories; he has calculated that the building and operation of the factories in Hrodna and Losośnia required about six million corvée labour days over fifteen years. Both Kościalkowski and Kula agree on the reasons for the decline of Tyzenhauz' factories in Hrodna; there was no market for goods that were more expensive and of poorer quality than imported ones. Most of Tyzenhauz' factories were closed by 1780 ; only a few continued to operate.

Apart from the studies by Kula and Kościalkowski Polish historians have produced books dealing with particular factories. B. Smoleńska has published materials on the history of the glassworks in Naliboki;"26 Z. Kamieńska has compiled a survey of the history of the glassworks in Urečča in the years 1737-1846. ${ }^{27}$ The work contains a detailed survey of contemporary glass production technology. The most important outlet for the factory's production was the court of the Radziwiłł family; the domestic market had only secondary significance. Kamienska estimates that from a capitalist point of view the factory was unprofitable since expenditure on wages was considerably in excess of return on investment. Free corvée labour was not included in production costs. For this reason the author advances the theory that the glassworks in Urečča existed for other than purely economic reasons, viz. to serve to the greater glory of the Radziwiłł family and as a means of influencing and subordinating their szlachta clientele.

The position of the peasantry in Byelorussia and Lithuania in the second half of the 18th century has been studied by Żytkowicz in a follow-up to the treatise by the Ukrainian historian D. L. Pochilewicz, Krest'jane Belorussii i Litvy vo vtoroj polovine XVIII veka (Vilna, 1936). ${ }^{28} \mathrm{~J}$. M. Lech has studied the fight against peasant unrest in Byelorussia in the 18th century during the Saxon period.".9 He deals in detail with the Byelorussian peasant uprising in Kryčaŭ in 1740, together with the use of troops of the Grand Duchy of Lithuania as well as the Radziwiłł militia to quell the disturbances. He draws attention to the contacts between the Ukrainian hajdamak movement in the middle of the 18th century and instances of rebellion by Byelorussian peasants against the feudal lords. Peasant unrest occurred in 
particular on the larger Byelorussian estates such as Kryčaŭ, Prapojsk, Cačersk, Horval, Rečyca, Mazyr, i.e. areas in south-eastern Byelorussia having close connections with the Ukraine.

Lech describes in detail the events of 1751 , when peasant revolts occurred in Paleśsie in connection with attacks by Ukrainian hajdamaki on Byelorussian territory. The disturbances were ruthlessly suppressed by the large landowners, especially by armed units of the Radziwiłł court. As Lech shows, the landowners had at their command regular units of hussars and infantry, grenadiers and musketeers. In 1751 under Prince Hieronim Florian Radziwiłł the Radziwiłł militia numbered 1750 men, with its chief garrison stationed in Słuck. It was used not only to put down peasant disturbances but also for civil war against other feudal lords.

The Radziwilł family made especial use of its militia in its fight against the peasant uprising in Kryčaŭ county (starostwo) of 1740-4. The peasants took up arms under the leadership of a certain Vaščyta against the Radziwiłł administration. The struggle against armed peasant rebellion in the areas of Kryčaŭ, Hłusk, Rečyca, Chalč and Żłobin was led chiefly by the Radziwiłł militia, not the regular army of the Grand Duchy.

In suppressing these rebellions the Radziwiłls were thinking not so much of the internal peace of the country as of settling their family and property affairs. Chalč and Žłobin were the dowry of the wife of Albert Radziwiłł.

The studies of J. Bardach are of fundamental importance for an understanding of the legal and political system of the Byelorussian lands. They cover the whole area of the former Grand Duchy of Lithuania, relying to a large extent on Byelorussian source material. Mention must be made in the first instance of his study of indivisible property in the Lithuanian statutes, his comparative study of sok, soczenie, prosoka*, mutual deeds of gift, petitioning and greeting, on the marriage law of the Slavonic peoples of the grand Duchy of Lithuania in the 15 th-17th centuries, ${ }^{30}$ tripartite division in Lithuanian property law, ${ }^{31}$ and finally his summary of previous research work on the Lithuanian statutes. ${ }^{32}$

Many Polish historians have made studies of Byelorussian history in the period of feudal decline. The conspiratorial movement in Lithuania and Byelorussia in the revolutionary year of 1848 is the subject of articles by D. Fajnhauz ${ }^{33}$ and M. Wierzchowski. ${ }^{34}$ The authors draw attention to the Polish conspiratorial groups that were active in these countries and aiming at setting up an independent republic. Among these groups the Fraternal Union led by the brothers Fr. and A. Dalewski was particularly distinguished. Agitation and conspiratorial activity in Byelorussia itself was being carried on in Minsk and the surrounding area by Mikołaj Bokij. He attempted to involve Byelorussian peasants in the prospective uprising. As we know, these organizations were exposed, and their members repressed by the tsarist regime.

* Translator's note: processes of criminal investigation 
P. Łossowski and Z. Młynarski bring to their readers' attention the little-known question of the participation of Russians, Byelorussiains and Ukrainians in preparations for the January uprising of $18633^{35} \mathrm{It}$ seems that the Byelorussian population took an active part in battles fought during the uprising. Also emphasized is the role played by Kastuś Kalinoŭski in inciting the Byelorussian peasantry to revolt through his publications and proclamations. At the same time the authors point out that there was little support for the 1863 uprising in central Byelorussia, i.e. the Minsk and Mahiloŭ provinces.

M. Kosman's Historia Biatorusi (Wrocław, 1979, 404 pp.) will come to have a certain degree of importance for the development of Polish research on Byelorussian history. The book gives rise to many reservations as to the method of exposition, periodization and fact; it is burdened with numerous important errors. It was not to be expected that Kosman would be able to cover all the facts of the history of Byelorussia and the Byelorussian people that he has chosen to set forth, in an often arbitrarily selective manner, in his book. Although he has made abundant use of work published by the Institute of History of the Byelorussian Academy of Sciences (including multivolume sets), he has not conducted independent research on source materials relating to the vast range of problems that he raises.

\section{NOTES}

H. Lowmiański and L. Zytkiewicz have produced a survey of work by Polish scholars published between 1945 and 1958: 'Istorija SSSR $v$ istoriografii NarodnoJ Pol'š', Istorija SSSR, 1960, 1, pp. 207-23; the most important pre-1967 work on the Grand Duchy of Lithuania is discussed by $\mathbf{H}$. Lowmiański in 'Dzieje narodów ZSRR oraz stosunki polsko-ruskie i polsko-rosyjskie (do końca XVIII w.) w historiografij Polski Ludowej', $Z$ dziejów stosunków polsko-radzieckich. Studia i materiaty, t. V, Warsaw, 1969, pp. 11-14.

1. S. Kasperczak, Rozwój gospodarki folwarcznej na Litwie i Biatorusi do polowy XVI w., Poznań, 1965, p. 396.

2. The question of the development of the large landholdings is dealt with in J. Ochmański, Powstanie $i$ rozwój lattfundium biskupstwa wileńsklego $w$ średniowieczu (1387-1550), Poznań, 1963; A. Wawrzyńczyk, Rozwój wielkiej wlasności na Podlasiu $w$ $\mathrm{XV}$ i XVI w., Wroclaw, 1951. (This publication is concerned solely with Brest district.)

3. S. Alexandrowicz, 'Geneza i rozwój sieci miasteczek Blałorusi i Litwy do polowy XVII wieku', Acta Baltica-Slavica, 7, Blałystok, 1970, pp. 47-108; ibid., 'Miasteczka Blałorusi i Litwy jako ośrodki handlu w XVI 1 w polowie XVII wieku', Roczntk Blatostocki, t. 1, 1961, pp. 63-130.

4. Alexandrowicz, 'Mapa W. Ks. Lltewsklego Tomasza Makowskiego z 1613 roku tzw. "radziwiłłowska" jako źródło do dzlejów Litwy i Białorusi', Studia Zródtoznawcze, t. 10, Poznań, 1965, pp. 33-67.

5. Alexandrowicz, 'Zaludnienie miasteczek Litwy i Białorusi w XVI 1 plerwszej połowie XVII wieku', Roczntki Dztejów Spotecznych i Gospodarczych, t. 27, Poznan, 1965, pp. 35-67.

6. Alexandrowicz, 'Klerunki produkcji rzemieślniczej 1 przemyslowej w miasteczkach Bialorusi i Litwy (XVI do polowy XVII w.)', Zeszyty Naukowe Uniwersytetu im. A. Mickiewicza. Historia, t. 6, Poznań, 1964, pp. 23-54.

7. Alexandrowicz, 'Miasta Blałorusi w XVI i picrwszej polowie XVII wieku', Kwartalntk historyczny, r. 75, z. 2, 1968, pp. 412-20.

8. Alexandrowicz, 'Nowe źródła ikonograficzne do oblężenia Polocka w 1579 r.', Kwartalnik Historil Kultury Materialnej, t. 19, no. 1, 1971, pp. 3-29.

9. Alexandrowicz, 'Ordynacja miasta Lubcza nad Niemnem w 1647 r.', Rocznik Historyczny, t. 3, 1982, pp. 439-48. 
10. Alexandrowicz, 'Rozwój kartografii Wielkiego Księstwa Litewskiego od XV do pol. XVIII w.', Uniwersytet im. A. Mickiewicza $w$ Poznaniu. Historia, no. 30, 1971, p. 142.

11. Ochmański, 'W kwestil agrarnego charakteru miast Wielkiego Księstwa Litewskiego w XVI w.', Studia Historica w 35-lecle pracy naukowej Henryka Lowmiańsklego, Warsaw, 1958.

12. Ochmański, 'Ludność litewska we wlości Obolce na Białorusi wschodniej $w$ XIV-XVI wieku', Acta Baltica-Slavica, t. 5, 1967, pp. 147-58.

13. Ochmański, 'Położenie spoleczno-gospodarcze i walka klasowa chłopów w ekonomti kobryńskiej w drugiej polowie XVI 1 pierwszej polowie XVII wleku', Roczniki Dziejów Spotecznych i Gospodarczych, t. 19, 1957 (publ. 1958), pp. 45-88.

14. Ochmański deals with the later stages of the development of large manorial estates in 'Gospodarka folwarczna $w$ dobrach gospodarskıch na Kobryńszczyźnie. Studium z dziejów folwarku na Białorusi, koniec XV - początek XVIII wieku', Kwartalnik Historit Kultury Materialnej, no. 3, 1958, pp. 365-95.

15. Ochmański, 'La grande réforme agraire en Lithuanie et en Ruthénie Blanche au XVI siècle', Ergon, II, 1960, pp. 327-41.

16. M. Kosman, 'Pomiara włóczna na Polesiu pińskim', Roczniki Dziejów Spolecznych i Gospodarczych, t. 31, 1970; ibid., Pomlara wtóczna. Opowiadanie o królowej Bonie, Warsaw, 1971, p. 75.

17. J. Kazimlerski, 'Opisanie krzywd wyrządzonych poddanym $w$ dobrach Holszany i Pasikiszki na Białorusi w 1554 roku', Przeglqd Historyczny, z. 4, 1962, pp. 809-18.

18. M. B. Topolska, Dobra szktowskie na Blatorusi wschodniej $w$ XVII $i$ XVIII wieku, Warsaw, 1969, p. 163.

19. Topolska, 'Szkłów i jego rola w gospodarce Blałorusi wschodniej w XVII i XVIII wieku', Roczniki Dziejów Spolecznych $i$ Gospodarczych, t. 30, 1969, pp. 1-32.

20. Topolska, 'Związki handlowe Blałorusi wschodniej z Ryga $w$ końcu XVII i na początku XVIII wieku', Roczniki Dziejów Spolecznych i Gospodarczych, t. 29, 1968, pp. 9-31.

21. Lowmiański, 'Popisy wojska Wielkiego Księstwa Litewskiego w. XVI jako żródlo do dziejów zaludnienia', Mediaevalia $w 50$ roczntce pracy naukowej Jana Dqbrowskiego, Warsaw, 1960, pp. 425-35.

22. J. Morzy, Kryzys demograficzny na Litwie i Biatorusi $w$ drugiej polowie XVII wieku, Poznań, 1965, p. 405.

23. W. Kula, Szkice o manufakturach $w$ Polsce XVIII w., Warsaw, 1956, p. 448.

24. S. Kościalkowski, Antont Tyzenhauz, podskarbi nadworny lttewskt, 2 vols, London, 1970-1.

25. L. Zytkowicz, 'Wokół Antoniego Tyzenhauza 1765-1780', Zapiski Historyczne, z. 2, 1974, pp. 53-76.

26. B. Smoleńska, 'Materiały do dziejów huty szklanej w Nallbokach $w$ XVIII w.', Teki archiwalne, 1, 1953, pp. 79-147.

27. Z. Kamieńska, Manufaktura szklana w Urzeczu 1737-1846, Warsaw, 1964, p. 240.

28. Zytkowicz, 'Chłopi na Białorusi i Litwie w II pol. XVIII w.', Kwartalnik Historyczny, r. 75 , 2. 1,1968 .

29. J. M. Lech, 'Powstanie chłopów bialoruskich w starostwie krzyczewskim 1740 r.', Przeglad Historyczny, z. 2, 1960, pp. 314-30; ibid., 'Mllicja radziwilłowska jako oręż w walce $z$ ruchami chłopskiml na Blałorusi i Litwie', Rocznik Biatostocki, t. 3, 1962, p. 33-60; ibtd, 'Wojsko W. Ks. Litewskiego $w$ doble saskiej $w$ walce $z$ ruchami chlopskimi na terente Bialorusi', Rocznik Biatostocki, t. 2, 1961, pp. 101-42.

30. Separate papers collected in: J. Bardach, Studia $z$ ustroju i prawa W. Ks. Litewskiego XIV-XVII $w$., Warsaw, 1970.

31. Bardach, 'Trzecizna w litewskim prawie majątkowym XV i XVI w.', Cultus et cognitio. Studia $z$ dziejow średniowlecznej kultury, Warsaw, 1976, pp. 81-95.

32. Bardach, 'Statuty Wielkiego Księstwa Litewskiego - pomniki prawa doby Odrodzenia'. Kwartalntk Historyczny, no. 4, 1974, pp. 750-80; ibid., Statuty litewskte - pomniki prawa epoki Odrodzenta, Cracow, 1973.

33. D. Fajnhauz, Ruch konspiracyjny na Litwie $i$ Biatorusi 1846-1848, Warsaw, 1965, p. 401; ibid., 'Rok 1848 na ziemiach Litwy 1 Bialorusi Zachodniej', Przeglad Historyczny, t. 48, 1957, pp. 683-706.

34.. M. Wierzchowski, ' $Z$ dziejów polskich organizacji spiskowych na terenie Litwy, Białorusi i Ukralny w latach 1848-1849', Rocznik Biatostockt, t. 3, 1962, pp. 73-95.

35. P. Eossowski and $Z$. Młynarski, Rosjante, Biatorusint $t$ Ukraincy $w$ powstaniu styczniowym, wroclaw, 1959, p. 239. 